\title{
Clinical Option of Pemetrexed-Based Versus Paclitaxel-Based First-Line Chemotherapeutic Regimens in Combination With Bevacizumab for Advanced Non-Squamous Non-Small-Cell Lung Cancer and Optimal Maintenance Therapy: Evidence From a Meta-Analysis of Randomized Control Trials
}

\author{
Le-Tian Huang \\ Shengjing Hospital of China Medical University, Department of Clinical Oncology \\ Rui Cao \\ Shengjing Hospital of China Medical University, Department of Clinical Oncology \\ Yan-Ru Wang \\ Shengjing Hospital of China Medical University, Department of Clinical Oncology \\ Li Sun \\ Shengjing Hospital of China Medical University, Department of Clinical Oncology \\ Xiang-Yan Zhang \\ Shengjing Hospital of China Medical University, Department of Clinical Oncology \\ Yi-Jia Guo \\ Shengjing Hospital of China Medical University, Department of Clinical Oncology \\ Jian-Zhu Zhao \\ Shengjing Hospital of China Medical University, Department of Clinical Oncology \\ Shu-Ling Zhang \\ Shengjing Hospital of China Medical University, Department of Clinical Oncology \\ Wei Jing \\ Shengjing Hospital of China Medical University, Department of Clinical Oncology \\ Jun Song \\ Shengjing Hospital of China Medical University, Department of Clinical Oncology \\ Cheng-Bo Han \\ Shengjing Hospital of China Medical University, Department of Clinical Oncology \\ Jie-tao Ma ( majt@sj-hospital.org ) \\ Shengjing Hospital of China Medical University https://orcid.org/0000-0003-2002-8628
}

Research article

Keywords: bevacizumab, first-line treatment, maintenance treatment, meta-analysis, non-small-cell lung cancer, paclitaxel, pemetrexed

Posted Date: August 5th, 2020

DOI: https://doi.org/10.21203/rs.3.rs-43694/v1

License: @ (i) This work is licensed under a Creative Commons Attribution 4.0 International License. Read Full License

Version of Record: A version of this preprint was published at BMC Cancer on April 17th, 2021. See the published version at https://doi.org/10.1186/s12885021-08136-5. 


\section{Abstract}

Background: In the era of immunotherapy, it is still unclear which is the best first-line therapy for patients with oncogenic driver negative advanced nonsquamous non-small cell lung cancer (NS-NSCLC) who cannot tolerate immunotherapy, or subsequent therapy for patients with oncogenic driver positive NSNSCLC whose disease progressed on prior targeted therapy. To assess the optimal choice of first-line and maintenance treatment regimens, we performed a meta-analysis of prospective randomized controlled clinical trials (RCTs) of patients with NS-NSCLC on bevacizumab combined with chemotherapy.

Methods: All eligible RCTs comparing pemetrexed-platinum with or without bevacizumab ( $\mathrm{PP} \pm \mathrm{B}$ ) and paclitaxel-carboplatin with bevacizumab (PC+B) as a first-line therapy, or comparing bevacizumab plus pemetrexed (Pem+B) and bevacizumab alone (B) as a maintenance treatment for advanced NS-NSCLC, were included after systematically searching web databases and meeting abstracts. The main research endpoints were comparisons of overall survival (OS) and progression-free survival (PFS). The other endpoints were objective response rate (ORR), 1-year PFS rate (PFSR1y) and major grade 3/4 treatment-related adverse events.

Results: Data of 3,139 patients from six RCTs were incorporated into analyses. Three RCTs were included in an analysis that compared PP $\pm \mathrm{B}$ and $\mathrm{PC}+\mathrm{B}$ as a first-line therapy for advanced NS-NSCLC. Patients treated with first-line PP \pm B showed similar OS and ORR, but significantly improved PFS (hazard ratio [HR], 0.88 ) and PFSR1y (risk ratio [RR], 0.83), as compared to patients treated with $P C+B(a l l ~ P<0.05)$. $P P \pm B$ resulted in higher rates of grade $3 / 4$ anemia and thrombocytopenia, but lower rates of neutropenia, febrile neutropenia, and sensory neuropathy than $P C+B(a l l ~ P<0.001)$. The other three RCTs were included in an analysis that compared Pem+B and B as a maintenance treatment. Compared with $B$, Pem+B maintenance treatment resulted in significant improvements in OS (HR, 0.88), PFS (HR, 0.64), and PFSR1y (RR, 0.70), but higher rates of anemia, thrombocytopenia, and neutropenia (all $P<0.001)$.

Conclusion: Although the first-line PP+B regimen had longer PFS and PFSR1y than the PC+B regimen, no OS difference was observed. Addition of pemetrexed to bevacizumab as maintenance therapy significantly improved OS compared with bevacizumab maintenance alone, but led to more toxicity.

\section{Background}

Lung cancer remains the cancer with the highest incidence and fatality rates worldwide [1]. With the development and clinical application of molecular targeted drugs and immune checkpoint inhibitors, the survival of patients with advanced non-small cell lung cancer (NSCLC) has significantly improved [2, 3]. Nevertheless, for patients with oncogenic driver negative non-squamous NSCLC (NS-NSCLC), especially patients with low or negative expression of programmed death-ligand 1 (PD-L1), platinum-based chemotherapy is still the cornerstone first-line treatment [4]. For patients with oncogenic driver (e.g., EGFR, ALK, and ROS1) positive NS-NSCLC whose disease progressed on prior targeted therapy, or patients with oncogenic driver negative NS-NSCLC who cannot tolerate immunotherapy, platinum-based chemotherapy with or without bevacizumab (a monoclonal antibody against vascular endothelial growth factor [VEGF]) remains the recommended first-line or subsequent therapy. Compared with chemotherapy alone, bevacizumab combined with chemotherapy can further prolong progression-free survival (PFS) and overall survival (OS) for patients with NS-NSCLC [5-8]. However, clinicians are still debating the better choice of first-line chemotherapy regimens (pemetrexed + platinum [PP] versus paclitaxel + carboplatin [PC]) in combination with bevacizumab.

In addition, in classic studies of AVAPERL and PARAMOUNT, advanced NS-NSCLC patients with disease control after 4 to 6 cycles of first-line induction chemotherapy can benefit from continuation maintenance treatment with bevacizumab (B), pemetrexed (Pem) or bevacizumab in combination with pemetrexed $($ Pem + B). However, PFS benefits with doublet maintenance did not translate into an OS advantage [9, 10]. Since two recent trials (COMPASS and EA5508) presented results on single-agent or doublet maintenance therapy at the 2019 American Society of Clinical Oncology meeting [11, 12], we conducted a meta-analysis of randomized control trials (RCTs) to assess the optimal first-line and maintenance regimens for NS-NSCLC patients who are assumed to be intolerant to immunotherapy, by comparing the efficacy and toxicity of first-line treatment regimens between $\mathrm{PP} \pm \mathrm{B}$ and $\mathrm{PC}+\mathrm{B}$, and maintenance treatment regimens between Pem $+B$, Pem, and $B$.

\section{Methods}

\section{Search strategy}

We identified eligible trials by an electronic search of the Cochrane library, PubMed, Embase, and Web of Science databases using the following terms: nonsmall cell lung cancer AND (pemetrexed OR bevacizumab OR paclitaxel). The search was performed on March 30, 2020. Two independent reviewers screened titles/abstracts and full text articles. The reference lists including related trials and review articles were manually retrieved.

\section{Selection criteria}

Eligible studies were RCTs of patients of untreated advanced NS-NSCLC who were randomized to receive treatment with cisplatin (or carboplatin) plus pemetrexed with or without bevacizumab $(\mathrm{PP} \pm \mathrm{B})$ or carboplatin plus paclitaxel with bevacizumab (PC+B), and to receive maintenance therapy (combined pemetrexed and bevacizumab or monotherapy with bevacizumab or pemetrexed). The main outcomes included at least one of the following: OS, PFS, objective response rate (ORR), or grade $\geq 3$ treatment-related adverse events (TRAEs).

\section{Data collection and quality assessment}

Characteristics of trials extracted were: first author's name, year of publication, patient characteristics, study name, study design and phase, sample size, treatment regimens of the study and control groups, maintenance regimens, and treatment cycles. Endpoints extracted were median PFS (mPFS), median OS (mOS), ORR, and grade $\geq 3$ TRAEs. Engauge Digitizer 10.8 software (produced by Mark Mitchell 2014; https://github.com/markummitchell/engauge-digitizer) was used to extract hazard ratio (HR) and 95\% confidence intervals (Cl), as well as other details (such as numbers at risk) from survival curves if no detailed 
HR values or numbers at risk were given. Trial quality was assessed with the methods recommended by the Cochrane Collaboration for assessing risk of bias [13]. The criteria used for quality assessment were randomization sequence generation, allocation concealment, blinding of participants and personnel, blinding of outcome assessment, incomplete outcome data, selective reporting, and other biases. Each item was categorized as having high, low, or unclear risk. Sensitivity analysis was performed for the primary outcome with the leave-one-out approach.

\section{Statistical analysis}

The meta-analysis was performed using STATA 12.0 (StataCorp, College Station). Analyses were stratified by trial. We compared the efficacy of each treatment regimen during the induction and maintenance phases. The evaluation included OS, PFS, ORR, and TRAEs. OS was evaluated from the beginning of randomized therapy until death due to any cause. PFS was defined as the beginning of randomized therapy until first event (progression or death from any cause). PFS and OS were expressed as HRs. The ORR, PFSR1y, and the rate of grade $\geq 3$ TRAEs were expressed as risk ratios (RRs). All p-values were twosided and were considered statistically significant at the 0.05 level. Heterogeneity was assessed with $\chi 2$ test $(a=0.1)$ and $I^{2}$ statistics. When statistics heterogeneity did not exist among studies $\left(P>0.10, I^{2}<50 \%\right)$, we used a fixed-effect model; if heterogeneity did exist $\left(P<0.10, l^{2}>50 \%\right)$, we found the cause and changed to a random-effect model.

\section{Results}

\section{Characteristics of included trials}

Based on the inclusion and exclusion criteria, six RCTs [9,11,12,14-16], including 3,144 NS-NSCLC patients were included in this meta-analysis. The baseline characteristics of the included studies are in Tables 1 and 2. Among them, three trials [14-16] were included in analysis comparing first-line treatment regimens between $\mathrm{PP} \pm \mathrm{B}$ and $\mathrm{PC}+\mathrm{B}$. Three other trials $[9,11,12]$ were included for analysis to compare maintenance regimens between $\mathrm{Pem}+\mathrm{B}$ and $\mathrm{B}$. The flow diagram of the literature retrieval and selection is in Figure 1.

\section{Comparisons of first-line therapy between $\mathrm{PP} \pm \mathrm{B}$ and $\mathrm{PC}+\mathrm{B}$}

Three RCTs including 1,418 patients were used to compare the efficacy and safety of PP $\pm B$ and PC+B [14-16], in which PP+B and PP subgroups were compared with PC+B. Indirect comparisons between subgroups of PP+B and PP were also analyzed.

\section{Efficacy}

The results of efficacy comparison are in Figure 2. Compared with $\mathrm{PC}+\mathrm{B}, \mathrm{PP} \pm \mathrm{B}$ showed a significant benefit in $\mathrm{mPFS}(\mathrm{HR} 0.88 ; 95 \% \mathrm{Cl}, 0.78$ to $0.99 ; \mathrm{P}=0.04)$ and PFSR1y (RR 0.83; $95 \% \mathrm{Cl}, 0.74$ to $0.93 ; \mathrm{P}=0.001)$, no significant differences were seen in $\mathrm{mOS}$ ( $\mathrm{HR} 1.01 ; 95 \% \mathrm{Cl}, 0.89$ to $1.14 ; \mathrm{P}=0.863)$, and ORR (RR 1.02 ; $95 \% \mathrm{Cl}, 0.92$ to $1.15 ; \mathrm{P}=0.675$ ) between the two groups. We also calculated pooled mPFS and mOS using a weighted average of single study medians because of insufficient data on $95 \% \mathrm{Cl}$ values [17]. For subgroups of PP $\pm \mathrm{B}$ vs. PC+B, mPFS was 5.77 vs. 5.80 months and moS was 12.16 vs. 13.04 months.

In the subgroup analysis, compared with PC+B group, a PP+B group showed improved mPFS (HR 0.83; $95 \% \mathrm{Cl}, 0.71$ to 0.97 ) and PFSR1y (RR 0.77; $95 \% \mathrm{Cl}$, 0.68 to 0.89 ) (all $P<0.05$ ), but no significant difference in ORR and mOS was observed between the two groups. A PP subgroup showed no advantage compared with a $\mathrm{PC}+\mathrm{B}$ group for any parameter. Indirect comparisons found no significant differences between $\mathrm{PP}+\mathrm{B}$ and $\mathrm{PP}$ in $\mathrm{mPFS}(\mathrm{P}=0.36)$, $\mathrm{PFSR} 1 \mathrm{y}$ $(P=0.11)$, mOS $(P=0.83)$, or ORR $(P=0.41)$.

\section{Safety}

The most common grade $\geq 3$ TRAEs were hematologic toxicities, hypertension, and sensory neuropathy. Compared with PC+B, PP \pm B had a significantly higher risk of anemia (RR 1.75; $95 \% \mathrm{Cl}, 1.58$ to $1.95 ; \mathrm{P}<0.001$ ) and thrombocytopenia (RR 1.70; $95 \% \mathrm{Cl}, 1.47$ to 1.96 ; $P<0.001$ ), but a significantly lower risk of neutropenia ( $R R 0.67 ; 95 \% \mathrm{Cl}, 0.59$ to $0.77 ; \mathrm{P}=0.000$ ), febrile neutropenia ( $R R$ 0.47; $95 \% \mathrm{Cl}, 0.25$ to $0.90 ; \mathrm{P}=0.023$ ), and sensory neuropathy ( $\mathrm{RR} 0.21 ; 95 \% \mathrm{Cl}$, 0.06 to $0.76 ; P=0.017)$. No significant differences were seen in hypertension $(P=0.117)$ or drug-related death $(P=0.491)$ between the two groups $($ Table 3$)$.

\section{Comparisons of maintenance treatment between Pem+B, Pem and $B$}

Three RCTs including 1,726 patients were used to compare the efficacy and safety of Pem+B and B maintenance [9,11,12]. Two RCTs used a continuation maintenance regimen in the study design $[9,11]$, and one study used continuation and switch maintenance regimens [12]. Indirect comparisons between Pem+B versus Pem maintenance and between Pem versus B maintenance were also analyzed.

\section{Efficacy}

The results of efficacy comparison are in Figure 3. Compared with B alone maintenance, Pem+B maintenance showed significant benefit in mPFS (HR 0.64; $95 \% \mathrm{Cl}, 0.57$ to $0.72 ; \mathrm{P}<0.001$ ), PFSR1y (RR 0.70; $95 \% \mathrm{Cl}, 0.63$ to $0.77 ; \mathrm{P}<0.001$ ), and $\mathrm{mOS}$ (HR 0.88; $95 \% \mathrm{Cl}, 0.78$ to $1.00 ; \mathrm{P}=0.05$ ). The $\mathrm{mPFS}$ and $\mathrm{mOS}$ (calculated using a weighted average of the single study medians) in subgroups Pem+B vs. B were 6.73 vs. 4.03 months and 19.39 vs. 16.36 months, respectively [17]. In subgroup analysis, compared with B maintenance, neither Pem+B continuation maintenance nor Pem+B switch maintenance showed obvious differences in mOS.

Indirect comparisons showed that mPFS ( $\mathrm{P}=0.024)$ and PFSR1y (odds ratio [OR] $0.57 ; 95 \% \mathrm{Cl}, 0.34$ to $0.95 ; \mathrm{P}=0.03$ ) were significantly improved in a Pem+B maintenance group compared with a Pem maintenance group, but with no significant difference in m0S between the two groups ( $P=0.855)$. Pem maintenance showed no benefit compared with B maintenance through indirect comparison of PFSR1y (OR 1.22; $95 \% \mathrm{Cl}, 0.76$ to $1.95 ; \mathrm{P}=0.41)$. 


\section{Safety}

The most common grade $\geq 3$ TRAEs were hematologic toxicities and hypertension. The risk of anemia (RR $1.75 ; 95 \% \mathrm{Cl}, 1.46$ to $2.09 ; \mathrm{P}<0.001)$, neutropenia (RR 1.95; $95 \% \mathrm{Cl}, 1.80$ to 2.12; $\mathrm{P}<0.001$ ), or thrombocytopenia (RR $1.88 ; 95 \% \mathrm{Cl}, 1.55$ to $2.28 ; \mathrm{P}<0.001$ ) were significantly higher in a Pem+B maintenance group than in a $\mathrm{B}$ alone maintenance group. No significant difference was observed in hypertension $(\mathrm{P}=0.864)$ between the two groups (Table 4).

\section{Quality of included studies and publication bias}

The risk of bias assessment of the included RCTs was low and is shown in Table 5; all studies were of high quality. To minimize publication bias, we executed strict inclusion criteria for selected papers and detected publication bias by several methods. No substantial asymmetry was found by visual inspection of the funnel plots. An Egger linear regression test and Begg rank correlation test also found no evidence of publication bias. Sensitivity analyses were conducted on PFS and OS to assess the heterogeneity in the first-line and maintenance phases. No significant heterogeneity in PFS or OS from any study was found.

\section{Discussion}

Chemotherapy combined with immunotherapy has become the current standard care for patients with negative oncogenic drivers regardless of squamous or non-squamous NSCLC or PD-L1 expression level [18]. However, some studies show that chemotherapy combined with the immunotherapy used in KEYNOTE189 or IMpower150 trial is not cost effective $[19,20]$. Several meta-analyses demonstrated that immunotherapy combined with chemotherapy led to more toxicities as grade $\geq 3$ TRAEs and more discontinuation of treatment than chemotherapy alone [18, 21]. In fact, chemotherapy plus bevacizumab is still an important first-line treatment option for patients with oncogenic driver negative NS-NSCLC who cannot tolerate immunotherapy, and is also a subsequent treatment for patients with oncogenic driver positive NS-NSCLC whose disease progressed on prior targeted therapy. Our study enhances understanding of the rational option of first-line chemotherapy regimens in combination with bevacizumab and the subsequent optimal maintenance therapy for these advanced NS-NSCLC cases. This study thus answers several controversial questions.

One question is which first-line chemotherapy regimen (pemetrexed- versus paclitaxel-based) is a better choice when used in combination with bevacizumab. Bevacizumab combined with platinum-based doublet chemotherapy shows clinical benefits for advanced NS-NSCLC in multiple RCTs, with mPFS of 6.2-9.2 months and mOS of 12.3-24.3 months [5-8]. A meta-analysis showed comparable efficacy for taxane and non-taxane regimens in combination with bevacizumab for treatment of patients with NS-NSCLC. For taxane and non-taxane groups, respective weighted mOS was 14.4 and 13.7 months $(P=0.5)$, mPFS was 6.93 and 6.99 months $(P=0.61)$, and ORR was $41 \%$ and $39 \%(P=0.65)$ [22]. Our meta-analysis found that $P P \pm B$ had a significant benefit for $P F S$ and PFSR1y, but no difference in OS and ORR between PP \pm B and PC $+B$. For subgroup comparisons with PC $+B, P P+B$ had significant benefits for PFS and PFSR1y, but not OS. The negative OS outcome may be attributed to the subsequent maintenance treatment options. Among three studies included for comparison of first-line treatments, PRONOUNCE and ERACLE studies used Pem alone as maintenance therapy; only the PointBreak study used Pem + B maintenance [14-16]. In our meta-analysis, the two groups had different grade $3 / 4$ toxicity profiles. In the PP $\pm B$ group, the risk of severe anemia was 1.75 times and the risk of thrombocytopenia was 1.7 times that in the PC + B group. In the PC + B group, the risk of severe sensory neuropathy was 4.76 times and the risk of febrile neutropenia was 2.13 times that in the PP \pm B group (Table 3 ). Since we saw no significant difference in OS between the two groups, the tolerance of patients to different drug toxicities should be considered when choosing first-line chemotherapies. That is, the choice of first-line chemotherapy mainly depends on differences in toxicity profiles.

The second question is which maintenance therapy (B versus Pem + B) is preferred. Maintenance therapy has emerged as a confirmed treatment strategy for advanced NSCLC. For NS-NSCLC patients, Pem + B in combination or as a single drug as a maintenance therapy is shown to be beneficial for survival [ 9,10 , 14 , 23]. Even though Pem + B showed significant benefits in PFS compared to monotherapy B maintenance, four previous studies did not recommend Pem + B as a standard maintenance regimen because of the lack of OS benefits and higher toxicity [9, 11, 12, 14]. Combining two recent RCTs [11, 12], our metaanalysis showed not only an improvement in PFS with Pem + B maintenance, but also a benefit in OS $(P=0.05)$. The PointBreak study showed a longer OS for Pem + B maintenance than B alone, but that trial could not be included in our meta-analysis, because the timepoint after random assignment was different from those in the other trials [14]. Although the addition of pemetrexed to bevacizumab as a maintenance therapy (Pem $+B)$ can moderately improve survival, we still need to be cautious, as doublet maintenance leads to more toxicities, especially hematological toxicity. In our meta-analysis, the risk of grade $3 / 4$ TRAEs including anemia, thrombocytopenia, and neutropenia were all significantly higher in the Pem + B groups. This may lead to a prolonged treatment interval, poor compliance with maintenance treatment, or even drug-related termination or death. Therefore, we recommend that only patients with NS-NSCLC with controlled disease after 4 to 6 cycles of PP + B induction therapy who have not experienced intolerable toxicity receive Pem + B continuation maintenance therapy whenever possible.

The third question is whether bevacizumab should be added to a PP regimen. Pemetrexed combined with platinum is the preferred frontline chemotherapy for patients with NS-NSCLC in National Comprehensive Cancer Network (NCCN) guidelines [24]. Efficacy of PP + B has been observed in some trials [9, 11, 14, 23], but no direct prospective comparison has been made between PP + B and PP. However, designing prospective trials comparing PP + B and PP seems increasingly infeasible. In both the PRONOUNCE and ERACLE study designs, bevacizumab was added to the PC regimen, but not to the PP regimen. Nevertheless, no significant difference in PFS or OS was observed between PP and PC + B [15, 16]. Our meta-analysis indicated that PP + B significantly prolonged PFS, as compared to PC + B, but no significant differences were seen in any survival data between PP + B and PP by indirect comparisons. However, the strength of the evidence to clarify this issue remains limited.

Currently, pembrolizumab in combination with chemotherapy is the preferred first-line regimen according to NCCN guidelines for patients with oncogenic driver negative NS-NSCLC and without contraindications to PD-1/PD-L1 inhibitors, regardless of PD-L1 expression level. Atezolizumab in combination with chemotherapy and bevacizumab is the other recommended regimen [25]. Interestingly, the chemotherapies in these two regimens differ (carboplatin/cisplatin 
+ pemetrexed, and carboplatin + paclitaxel, respectively). In the future, we should focus on whether bevacizumab is a good partner to combine with chemotherapy and anti-PD-1 immunotherapy (e.g., pembrolizumab) for both first-line and maintenance treatment.

In our meta-analysis, we strictly limited the inclusion criteria to RCTs. However, summary statistics rather than individual patient data were used for each trial, and the studies included were heterogeneous, with varying patient populations and different study designs. For example, EGFR-sensitizing mutation populations were excluded in the COMPASS trial, but not mentioned in the other five trials. This difference may lead to different subsequent line regimens and survival.

\section{Conclusions}

This study demonstrated that PP + B as first-line therapy is as effective as PC + B in patients with advanced NS-NSCLC, and the toxicity profile of the two therapies varies. Addition of pemetrexed to bevacizumab as maintenance therapy significantly improved survival, but led to more toxicity. Patients' tolerance and toxicity profiles should be considered when choosing treatment regimens. On the basis of the answers to these three questions, we have made preliminary recommendations for first-line and maintenance treatment strategies for patients with advanced NS-NSCLC with negative drivers who cannot tolerate immunotherapy, and for patients with positive oncogenic drivers whose disease progressed on prior targeted therapy. Treatment with PP $+\mathrm{B}$ or $\mathrm{PC}+\mathrm{B}$ followed by Pem $+B$ rather than single-drug B or Pem maintenance might be the best choice under the premise of tolerable toxicity.

\section{List Of Abbreviations}

NSCLC: non-small cell lung cancer; NS-NSCLC: non-squamous NSCLC; PD-L1: programmed death-ligand 1; RCTs: randomized controlled clinical trials; VEGF: vascular endothelial growth factor; $\mathrm{PP} \pm \mathrm{B}$ : pemetrexed-platinum with or without bevacizumab; $\mathrm{PC}+\mathrm{B}$ : paclitaxel-carboplatin with bevacizumab; Pem+B: pemetrexed and bevacizumab; TRAEs: treatment-related adverse events; Cl: confidence intervals; ORR: objective response rate; OS: overall survival; PFS: progress free survival; PFSR1y: 1-year PFS rate; HR: hazard ratio; RR: risk ratio; NCCN: National Comprehensive Cancer Network.

\section{Declarations}

\section{Ethics approval and consent to participate}

Not applicable

\section{Consent for publication}

Not applicable

\section{Availability of data and materials}

The data that support the findings of this study are available from the corresponding author upon reasonable request.

\section{Competing interests}

The authors declare no conflict of interest.

\section{Funding}

This study was supported by grants from the 345 Talent Project of Shengjing Hospital.

\section{Authors' contributions}

All of the authors have read and approved the final manuscript. LH, JM and CH conceived and designed the study. LH, RC, YW, LS, and XZ took full responsibility for data collecting. LH, JZ, SZ, WJ and JS performed the meta-analysis, systematic review, and drafted the manuscript. CH and JM helped revise the manuscript.

\section{Acknowledgments}

The authors thank all the medical staff who contributed to the maintenance of the medical record database.

\section{References}

1. Bray F, Ferlay J, Soerjomataram I, Siegel RL, Torre LA, Jemal A. Global cancer statistics 2018: GLOBOCAN estimates of incidence and mortality worldwide for 36 cancers in 185 countries. CA: a cancer journal for clinicians. 2018;68:394-424. https://doi.org/10.3322/caac.21492

2. Reck M, Rodriguez-Abreu D, Robinson AG, Hui R, Csoszi T, Fulop A, et al. Updated analysis of KEYNOTE-024: pembrolizumab versus platinum-based chemotherapy for advanced non-small-cell lung cancer with PD-L1 tumor proportion score of 50\% or greater. J Clin Oncol. 2019;37:537-546. https://doi.org/1200/JCO.18.00149

3. Dong J, Li B, Zhou Q, D Lin, D Huang. Advances in targeted therapy and immunotherapy for Non-Small Cell Lung Cancer based on accurate molecular typing. Frontiers in Pharmacology. 2019;10:230. https://doi.org/3389/fphar.2019.00230 
4. Ettinger DS, Wood DE, Aggarwal C, Aisner DL, Akerley W, Bauman JR, et al. NCCN Guidelines Insights: Non-Small Cell Lung Cancer, Version 1.2020: Featured Updates to the NCCN Guidelines. Journal of the National Comprehensive Cancer Network. 2019;17:1464-1472.

https://doi.org/6004/jnccn.2019.0059

5. Sandler A, Gray R, Perry MC, Brahmer J, Schiller JH, Dowlati A, et al. Paclitaxel-carboplatin alone or with bevacizumab for nonsmall-cell lung cancer. N Engl J Med. 2006;355:2542-2550. https://doi.org/ 10.1056/NEJMoa061884

6. Zhou C, Wu YL, Chen G, Liu X, Zhu Y, Lu S, et al. BEYOND: a randomized, double-blind, placebo-controlled, multicenter, phase III study of first-line carboplatin/ paclitaxel plus bevacizumab or placebo in chinese patients with advanced or recurrent nonsquamous non-small-cell lung cancer. $\mathrm{J}$ Clin Oncol. 2015;33:2197-2204. https://doi.org/1200/JC0.2014.59.4424

7. Johnson DH, Fehrenbacher L, Novotny WF, Herbst RS, Nemunaitis JJ, Jablons DM, et al. Randomized phase II trial comparing bevacizumab plus carboplatin and paclitaxel with carboplatin and paclitaxel alone in previously untreated locally advanced or metastatic nonsmall-cell lung cancer. $\mathrm{J}$ Clin Oncol. 2004;22:2184-2191. https://doi.org/ 10.1200/jco.2004.11.022

8. Niho S, Kunitoh H, Nokihara H, Horai T, Ichinose Y, Hida T, et al. Randomized phase II study of first-line carboplatin-paclitaxel with or without bevacizumab in Japanese patients with advanced non-squamous non-smallcell lung cancer. Lung Cancer. 2012;76:362-367. https://doi.org/ 10.1016/j.lungcan.2011.12.005

9. Barlesi F, Scherpereel A, Rittmeyer A, Pazzola A, Ferrer TN, Kim JH, et al. Randomized phase III trial of maintenance bevacizumab with or without pemetrexed after first-line induction with bevacizumab, cisplatin, and pemetrexed in advanced nonsquamous non-small-cell lung cancer: AVAPERL (MO22089). Journal of Clinical Oncology. 2013;31:3004-3011. https://doi.org/ 10.1200/JC0.2012.42.3749

10. Paz-Ares L, de Marinis F, Dediu M, Thomas M, Pujol JL, Bidoli P, et al. Maintenance therapy with pemetrexed plus best supportive care versus placebo plus best supportive care after induction therapy with pemetrexed plus cisplatin for advanced non-squamous non-small-cell lung cancer (PARAMOUNT): a double-blind, phase 3, randomised controlled trial. Lancet Oncol. 2012;13:247-255. https://doi.org/ 1016/S1470-2045(12)70063-3

11. Seto T, Azuma K, Yamanaka T, Sugawara S, Yoshioka H, Wakuda K, et al. Randomized Phase III Study of Continuation Maintenance Bevacizumab With or Without Pemetrexed in Advanced Nonsquamous Non-Small-Cell Lung Cancer: COMPASS (WJOG5610L). J Clin Oncol. 2019;JCO:19. https://doi.org/ $10.1200 / J C 0.19 .01494$

12. Ramalingam SS, Dahlberg SE, Belani CP, Saltzman JN, Pennell NA, Nambudiri GS, et al. Pemetrexed, bevacizumab, or the combination as maintenance therapy for advanced nonsquamous non-small-cell lung cancer: ECOG-ACRIN 5508. J Clin Oncol. 2019;37:2360-2367. https://doi.org/ $10.1200 / J C 0.19 .01006$

13. Higgins JP, Altman DG. Assessing risk of bias in included studies. In: Higgins JP, Green S, eds. Cochrane handbook for systematic reviews of interventions: Cochrane book series. Chichester: John Wiley \& Sons, 2008;187-241.

14. Patel JD, Socinski MA, Garon EB, Reynolds CH, Spigel DR, Olsen MR, et al. PointBreak: a randomized phase III study of pemetrexed plus carboplatin and bevacizumab followed by maintenance pemetrexed and bevacizumab versus paclitaxel plus carboplatin and bevacizumab followed by maintenance bevacizumab in patients with stage IIIB or IV nonsquamous non-small-cell lung cancer. J Clin Oncol. 2013;31:4349. https://doi.org/ $10.1200 / J C 0.2012 .47 .9626$

15. Zinner RG, Obasaju CK, Spigel DR, Weaver RW, Beck JT, Waterhouse DM et al. PRONOUNCE: randomized, open-label, phase III study of first-line pemetrexed 1 carboplatin followed by maintenance pemetrexed versus paclitaxel 1 carboplatin 1 bevacizumab followed by maintenance bevacizumab in patients ith advanced nonsquamous non-small-cell lung cancer. J Thorac Oncol. 2015;10:134-142. https://doi.org/ 10.1097/JT0.0000000000000366

16. Galetta D, Cinieri S, Pisconti S, Gebbia V, Morabito A, Borsellino N, et al. Cisplatin/pemetrexed followed by maintenance pemetrexed versus carboplatin/paclitaxel/bevacizumab followed by maintenance bevacizumab in advanced nonsquamous lung cancer: the GOIM (Gruppo Oncologico Italia Meridionale) ERACLE phase III randomized trial. Clin Lung Cancer. 2015;16:262-273. https://doi.org/ 10.1016/j.cllc.2014.12.002

17. Ma JT, Sun J, Sun L, Zhang SL, Huang LT, Han CB. Efficacy and safety of apatinib in patients with advanced nonsmall cell lung cancer that failed prior chemotherapy or EGFR-TKIs: a pooled analysis. Medicine. 2018;97:e12083. https://doi.org/ 10.1097/MD.0000000000012083

18. Cao R, Ma JT, Zhang SL, Sun L, Liu Y, Zhang XY, et al. Rational application of the first-line chemotherapy and immune checkpoint inhibitors in advanced nonsmall cell lung cancer: A meta- Cancer medicine. 2019;8:5033-5046. https://doi.org/ 10.1002/cam4.2407

19. Wan N, Zhang T, Hua S, Lu Z, Ji B, Li L, et al. Cost-effectiveness analysis of pembrolizumab plus chemotherapy with PD-L1 test for the first-line treatment of NSCLC. Cancer Medicine. 2020;9:1683-1693. https://doi.org/ 10.1002/cam4.2793

20. Criss SD, Mooradian MJ, Watson TR, Gainor JF, Reynolds KF, Kong Ck, et al. Cost-effectiveness of Atezolizumab Combination Therapy for First-Line Treatment of Metastatic Nonsquamous Non-Small Cell Lung Cancer in the United States. JAMA network open. 2019;2:e1911952-e1911952. https://doi.org/ 10.1001/jamanetworkopen.2019.11952

21. Chen Y, Zhou Y, Tang L, Peng X, Jiang H, Wang G, et al. Immune-Checkpoint Inhibitors as the First Line Treatment of Advanced Non-Small Cell Lung Cancer: A Meta-Analysis of Randomized Controlled Trials. Journal of Cancer. 2019;10: 6261-6268. https://doi.org/ 10.7150/jca.34677

22. Socinski MA, Jotte RM, Cappuzzo F, Orlandi F, Stroyakovskiy D, Nogami N, et al. Atezolizumab for first-line treatment of metastatic nonsquamous NSCLC. New England Journal of Medicine. 2018;378: 2288-2301. https://doi.org/ 10.1056/NEJMoa1716948

23. Behera M, Pillai RN, Owonikoko TK, Kim S, Steuer C, Chen Z, et al. Bevacizumab in combination with taxane versus non-taxane containing regimens for advanced/metastatic Nonsquamous Non-Small-Cell Lung Cancer: A systematic review. Journal of Thoracic Oncology. 2015;10:1142-1147. https://doi.org/ 10.1097/JT0.0000000000000572

24. Karayama M, Inui N, Fujisawa T, Enomoto N, Nakamura Y, Kuroishi S, et al. Maintenance therapy with pemetrexed and bevacizumab versus pemetrexed monotherapy after induction therapy with carboplatin, pemetrexed, and bevacizumab in patients with advanced non-squamous non small cell lung cancer. Eur J Cancer. 2016;58:30-37. https://doi.org/ 10.1016/j.ejca.2016.01.013

Page 6/12 
25. Masters GA, Temin S, Azzoli CG, Giaccone G, Baker S Jr, Brahmer JR, et al. Systemic therapy for stage IV non-small-cell lung cancer: American society of clinical oncology clinical practice guideline update. J Clin Oncol. 2015;33:3488-3515. https://doi.org/ 10.1200/JC0.2015.62.1342

\section{Tables}


Table 1

Characteristics of the included studies

\begin{tabular}{|c|c|c|c|c|c|c|c|c|}
\hline $\begin{array}{l}\text { Author/published } \\
\text { year }\end{array}$ & $\begin{array}{l}\text { Induction } \\
\text { arms } \\
\text { (randomized) }\end{array}$ & $\begin{array}{l}\text { Induction } \\
\text { sample } \\
\text { size }\end{array}$ & $\begin{array}{l}\text { Induction } \\
\text { regimen }\end{array}$ & $\begin{array}{l}\text { Induction } \\
\text { Cycles }\end{array}$ & $\begin{array}{l}\text { Dose of } \\
\text { Bevacizumab }\end{array}$ & $\begin{array}{l}\text { Maintenance arms } \\
\text { (randomized) }\end{array}$ & Maintenance sample size & $\begin{array}{l}\mathrm{Pr} \\
\text { en }\end{array}$ \\
\hline \multirow[t]{2}{*}{$\begin{array}{l}\text { Patel, } 2013 \\
\text { (PointBreak) }\end{array}$} & $\begin{array}{l}\text { Pem + Cb + } \\
\text { Bev } \\
\text { (randomized) }\end{array}$ & 442 & $\begin{array}{l}\text { Pem } \\
500 \mathrm{mg} / \mathrm{m} 2 \text {, } \\
\mathrm{Cb} \text { AUC } 6, \\
\text { Bev } \\
15 \mathrm{mg} / \mathrm{kg}, \\
\text { day } 1 \text { every } \\
3 \text { weeks }\end{array}$ & 4 & $15 \mathrm{mg} / \mathrm{kg}$ & $\mathrm{Pem}+\mathrm{Bev}$ & 292 & $0 ؟$ \\
\hline & $\begin{array}{l}\mathrm{Pac}+\mathrm{Cb}+ \\
\mathrm{Bev} \\
\text { (randomized) }\end{array}$ & 443 & $\begin{array}{l}\mathrm{Pac} \\
200 \mathrm{mg} / \mathrm{m} 2 \text {, } \\
\mathrm{Cb} \text { AUC } 6, \\
\mathrm{Bev} \\
15 \mathrm{mg} / \mathrm{kg}, \\
\text { day } 1 \text { every } \\
3 \text { weeks }\end{array}$ & & & $\mathrm{Bev}$ & 298 & \\
\hline \multirow[t]{2}{*}{$\begin{array}{l}\text { Zinner, } 2015 \\
\text { (PRONOUNCE) }\end{array}$} & $\begin{array}{l}\text { Pem + Cb } \\
\text { (randomized) }\end{array}$ & 182 & $\begin{array}{l}\text { Pem } \\
500 \mathrm{mg} / \mathrm{m} 2 \text {, } \\
\text { Cb AUC 6, } \\
\text { day } 1 \text { every } \\
3 \text { weeks }\end{array}$ & 4 & $15 \mathrm{mg} / \mathrm{kg}$ & Pem & 121 & $\begin{array}{l}\mathrm{PF} \\
\mathrm{gr} \\
\text { to: }\end{array}$ \\
\hline & $\begin{array}{l}\mathrm{Pac}+\mathrm{Cb}+ \\
\mathrm{Bev} \\
\text { (randomized) }\end{array}$ & 179 & $\begin{array}{l}\mathrm{Pac} \\
200 \mathrm{mg} / \mathrm{m} 2 \text {, } \\
\mathrm{Cb} \text { AUC } 6, \\
\mathrm{Bev} \\
15 \mathrm{mg} / \mathrm{kg}, \\
\text { day } 1 \text { every } \\
3 \text { weeks }\end{array}$ & & & $\mathrm{Bev}$ & 113 & \\
\hline \multirow[t]{2}{*}{$\begin{array}{l}\text { Galetta, } 2015 \\
\text { (ERACLE) }\end{array}$} & $\begin{array}{l}\text { Pem + Cis } \\
\text { (randomized) }\end{array}$ & 60 & $\begin{array}{l}\text { Pem } \\
500 \text { mg/m2, } \\
\text { Cis } \\
75 \mathrm{mg} / \mathrm{m} 2 \text {, } \\
\text { day } 1 \text { every } \\
3 \text { weeks }\end{array}$ & 6 & $15 \mathrm{mg} / \mathrm{kg}$ & Pem & 44 & Q( \\
\hline & $\begin{array}{l}\mathrm{Pac}+\mathrm{Cb}+ \\
\mathrm{Bev} \\
\text { (randomized) }\end{array}$ & 58 & $\begin{array}{l}\text { Pac } \\
200 \text { mg/m2, } \\
\text { Cb AUC } 6 \\
\text { Bev } \\
15 \text { mg/kg, } \\
\text { day } 1 \text { every } \\
3 \text { weeks }\end{array}$ & & & $\mathrm{Bev}$ & 30 & \\
\hline \multirow[t]{2}{*}{$\begin{array}{l}\text { Barlesi, } 2014 \\
\text { (AVAPERL) }\end{array}$} & $\begin{array}{l}\mathrm{Pem}+\mathrm{Cis}+ \\
\mathrm{Bev}\end{array}$ & 376 & $\begin{array}{l}\text { Pem } \\
500 \mathrm{mg} / \mathrm{m} 2 \text {, } \\
\text { Cis } \\
75 \mathrm{mg} / \mathrm{m} 2 \text {, } \\
\text { Bev } \\
7.5 \mathrm{mg} / \mathrm{kg} \text {, } \\
\text { day } 1 \text { every } \\
3 \text { weeks }\end{array}$ & 4 & $7.5 \mathrm{mg} / \mathrm{kg}$ & $\begin{array}{l}\text { Pem + Bev } \\
\text { (randomized) }\end{array}$ & 128 & $\mathrm{PF}$ \\
\hline & & & & & & $\begin{array}{l}\text { Bev } \\
\text { (randomized) }\end{array}$ & 125 & \\
\hline \multirow[t]{2}{*}{$\begin{array}{l}\text { Ramalingam, } \\
2019 \text { (EA5508) }\end{array}$} & $\begin{array}{l}\mathrm{Pac}+\mathrm{Cb}+ \\
\mathrm{Bev}\end{array}$ & 1432 & $\begin{array}{l}\mathrm{Pac} \\
200 \mathrm{mg} / \mathrm{m} 2 \text {, } \\
\mathrm{Cb} \mathrm{AUC} 6, \\
\mathrm{Bev} \\
15 \mathrm{mg} / \mathrm{kg}, \\
\text { day } 1 \mathrm{every} \\
3 \text { weeks }\end{array}$ & 4 & $15 \mathrm{mg} / \mathrm{kg}$ & $\begin{array}{l}\text { Bev } \\
\text { (randomized) }\end{array}$ & 287 & $0 \leqslant$ \\
\hline & & & & & & $\begin{array}{l}\text { Pem } \\
\text { (randomized) }\end{array}$ & 294 & \\
\hline
\end{tabular}




\begin{tabular}{|c|c|c|c|c|c|c|c|c|}
\hline $\begin{array}{l}\text { Author/published } \\
\text { year }\end{array}$ & $\begin{array}{l}\text { Induction } \\
\text { arms } \\
\text { (randomized) }\end{array}$ & $\begin{array}{l}\text { Induction } \\
\text { sample } \\
\text { size }\end{array}$ & $\begin{array}{l}\text { Induction } \\
\text { regimen }\end{array}$ & $\begin{array}{l}\text { Induction } \\
\text { Cycles }\end{array}$ & $\begin{array}{l}\text { Dose of } \\
\text { Bevacizumab }\end{array}$ & $\begin{array}{l}\text { Maintenance arms } \\
\text { (randomized) }\end{array}$ & Maintenance sample size & $\begin{array}{l}\text { Pr } \\
\text { en }\end{array}$ \\
\hline & & & & & & Pem + Bev & 293 & \\
\hline & & & & & & (randomized) & & \\
\hline \multirow{4}{*}{$\begin{array}{l}\text { Seto, } 2019 \\
\text { (COMPASS) }\end{array}$} & $\underset{\mathrm{Bey}}{\mathrm{Pem}}+\mathrm{Cb}+$ & 907 & & 4 & $15 \mathrm{mg} / \mathrm{kg}$ & Bev & 295 & Os \\
\hline & & & $\begin{array}{l}\mathrm{Cb} \text { AUC } 6 \text {, } \\
\text { Bev } \\
15 \mathrm{mg} / \mathrm{kg}, \\
\text { day } 1 \text { every } \\
3 \text { weeks }\end{array}$ & & & (randomized) & & As \\
\hline & & & & & & Pem + Bev & 299 & \\
\hline & & & & & & (randomized) & & \\
\hline
\end{tabular}

Abbreviation: AUC, area under the curve; Bev, bevacizumab; Cb, carboplatin; Cis, cisplatin; DCR, disease control rate; DOR, duration of response; ORR, objectiv $\epsilon$ overall survival; Pac, paclitaxel; Pem, pemetrexed; PFS, progress free survival; QOL, quality of life; TTPD, time to progressive disease.

Table 2

Clinicopathological characteristics of the included patients

\begin{tabular}{|c|c|c|c|c|c|c|c|}
\hline Study & Randomized arms & Age, Median (y) & Stage IV (\%) & Male (\%) & ECOG PS $1(\%)$ & Never Smoker (\%) & $\begin{array}{l}\text { Adenocarcinoma } \\
\text { (\%) }\end{array}$ \\
\hline \multirow[t]{2}{*}{ PointBreak } & $P P+B$ & 64.6 & $89.8 \%$ & $53.2 \%$ & $56.1 \%$ & $10.6 \%$ & $80.1 \%$ \\
\hline & $P C+B$ & 64.9 & $90.1 \%$ & $53.3 \%$ & $55.6 \%$ & $12.5 \%$ & $78.3 \%$ \\
\hline \multirow[t]{2}{*}{ PRONOUNCE } & PP & 65.8 & $99.5 \%$ & $57.7 \%$ & $52.7 \%$ & $19.9 \%$ & $83.5 \%$ \\
\hline & $P C+B$ & 65.4 & $100.0 \%$ & $58.1 \%$ & $53.1 \%$ & $3.9 \%$ & $76.5 \%$ \\
\hline \multirow[t]{2}{*}{ ERACLE } & PP & 60.0 & $95.0 \%$ & $70.0 \%$ & $22.0 \%$ & $22.0 \%$ & $97.0 \%$ \\
\hline & $P C+B$ & 62.0 & $93.0 \%$ & $78.0 \%$ & $21.0 \%$ & $28.0 \%$ & $97.0 \%$ \\
\hline \multirow[t]{2}{*}{ AVAPERL } & Pem + B & 60.0 & $94.4 \%$ & $57.6 \%$ & $46.0 \%$ & $24.8 \%$ & $85.6 \%$ \\
\hline & B & 60.0 & $89.2 \%$ & $56.7 \%$ & $55.6 \%$ & $26.1 \%$ & $91.7 \%$ \\
\hline \multirow[t]{3}{*}{ EA5508 } & B & 65.0 & $93.0 \%$ & $49.0 \%$ & $57.0 \%$ & $10.0 \%$ & $91.0 \%$ \\
\hline & Pem & 63.0 & $93.0 \%$ & $49.0 \%$ & $54.0 \%$ & $11.0 \%$ & $88.0 \%$ \\
\hline & Pem + B & 64.0 & $93.0 \%$ & $49.0 \%$ & $55.0 \%$ & $11.0 \%$ & $91.0 \%$ \\
\hline \multirow[t]{2}{*}{ COMPASS } & Pem + B & 65.0 & $92.2 \%$ & $73.9 \%$ & $38.5 \%$ & $24.7 \%$ & $96.7 \%$ \\
\hline & B & 65.0 & $90.4 \%$ & $70.8 \%$ & $42.0 \%$ & $20.0 \%$ & $96.3 \%$ \\
\hline
\end{tabular}


Table 3

Summary of forest plot for TRAEs (PP $\pm \mathrm{B} v s$. $\mathrm{PC}+\mathrm{B}$ )

\begin{tabular}{|c|c|c|c|c|c|c|}
\hline TRAEs & $\begin{array}{l}P P \pm B \\
n / N(\%)\end{array}$ & $\begin{array}{l}P C+B \\
n / N(\%)\end{array}$ & $\begin{array}{l}\text { Heterogeneity } \\
\mathrm{I}^{2}\end{array}$ & Heterogeneity P value & $\mathrm{RR}(95 \% \mathrm{Cl})$ & $P$ value \\
\hline Drug-related deaths & $9 / 684(1.3 \%)$ & $13 / 680(1.9 \%)$ & $0 \%$ & 0.845 & $0.84(0.52,1.37)$ & 0.491 \\
\hline \multicolumn{7}{|l|}{ Grade 3/4 TRAEs } \\
\hline \multirow[t]{2}{*}{ Anemia } & $97 / 684$ & $23 / 680(3.4 \%)$ & $2.3 \%$ & 0.359 & $1.75(1.58,1.95)$ & 0.000 \\
\hline & $(14.2 \%)$ & & & & & \\
\hline \multirow[t]{2}{*}{ Hypertension } & $15 / 684$ & $29 / 680(4.3 \%)$ & $0 \%$ & 0.546 & $0.73(0.49,1.08)$ & 0.117 \\
\hline & $(2.2 \%)$ & & & & & \\
\hline Neutropenia & $161 / 684(23.5 \%)$ & $267 / 680(39.3 \%)$ & $1.0 \%$ & 0.364 & $0.67(0.59,0.77)$ & 0.000 \\
\hline Thrombocytopenia & $144 / 684(21.1 \%)$ & $42 / 680(6.2 \%)$ & $25.3 \%$ & 0.262 & $1.70(1.47,1.96)$ & 0.000 \\
\hline Sensory neuropathy & $1 / 684(0.1 \%)$ & $26 / 680(3.8 \%)$ & $0 \%$ & 0.384 & $0.21(0.06,0.76)$ & 0.017 \\
\hline Febrile neutropenia & $6 / 684(0.9 \%)$ & $22 / 680(3.2 \%)$ & $0 \%$ & 0.875 & $0.47(0.25,0.90)$ & 0.023 \\
\hline
\end{tabular}

Table 4

Summary of forest plot for grade 3/4 TRAEs (Pem + B vs. B maintenance)

\begin{tabular}{|l|l|l|l|l|l|l|}
\hline $\begin{array}{l}\text { Grade 3/4 } \\
\text { TRAEs }\end{array}$ & $\begin{array}{l}\text { Pem + B } \\
\text { n/N (\%) }\end{array}$ & $\begin{array}{l}\text { B } \\
\text { n/N (\%) }\end{array}$ & Heterogeneity I & Heterogeneity P value & RR (95\%Cl) & P value \\
\hline Anemia & $35 / 620(5.6 \%)$ & $7 / 707(1.0 \%)$ & $41.8 \%$ & 0.179 & $1.75(1.46,2.09)$ & 0.000 \\
\hline Hypertension & $97 / 620(15.6 \%)$ & $98 / 707(13.9 \%)$ & $60.8 \%$ & 0.078 & $1.02(0.78,1.34)$ & 0.864 \\
\hline Neutropenia & $81 / 620(13.1 \%)$ & $6 / 707(0.8 \%)$ & $0 \%$ & 0.872 & $1.95(1.80,2.12)$ & 0.000 \\
\hline Thrombocytopenia & $14 / 620(2.3 \%)$ & $1 / 707(1.0 \%)$ & $10.4 \%$ & 0.291 & $1.88(1.55,2.28)$ & 0.000 \\
\hline Abbreviation: Pem + B, pemetrexed and bevacizumab; B, bevacizumab; RR, risk ratio; TRAEs, treatment-related adverse events.
\end{tabular}

Table 5

Evaluation of risk of bias in the included studies.

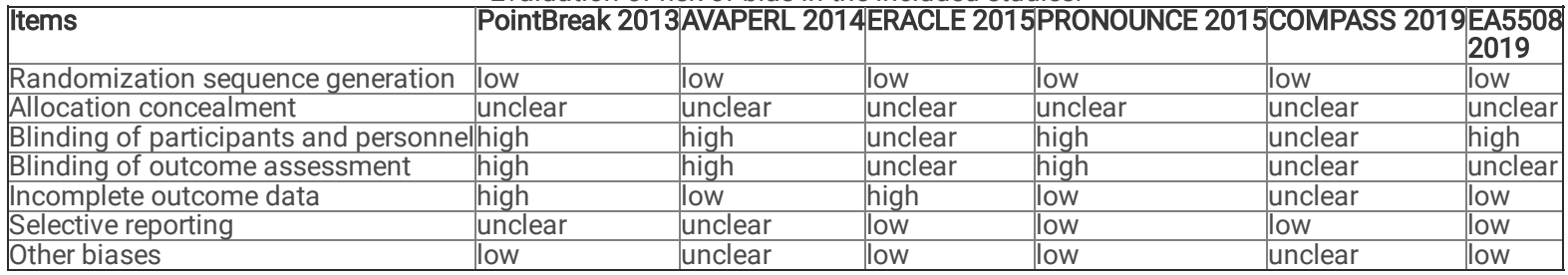

\section{Figures}




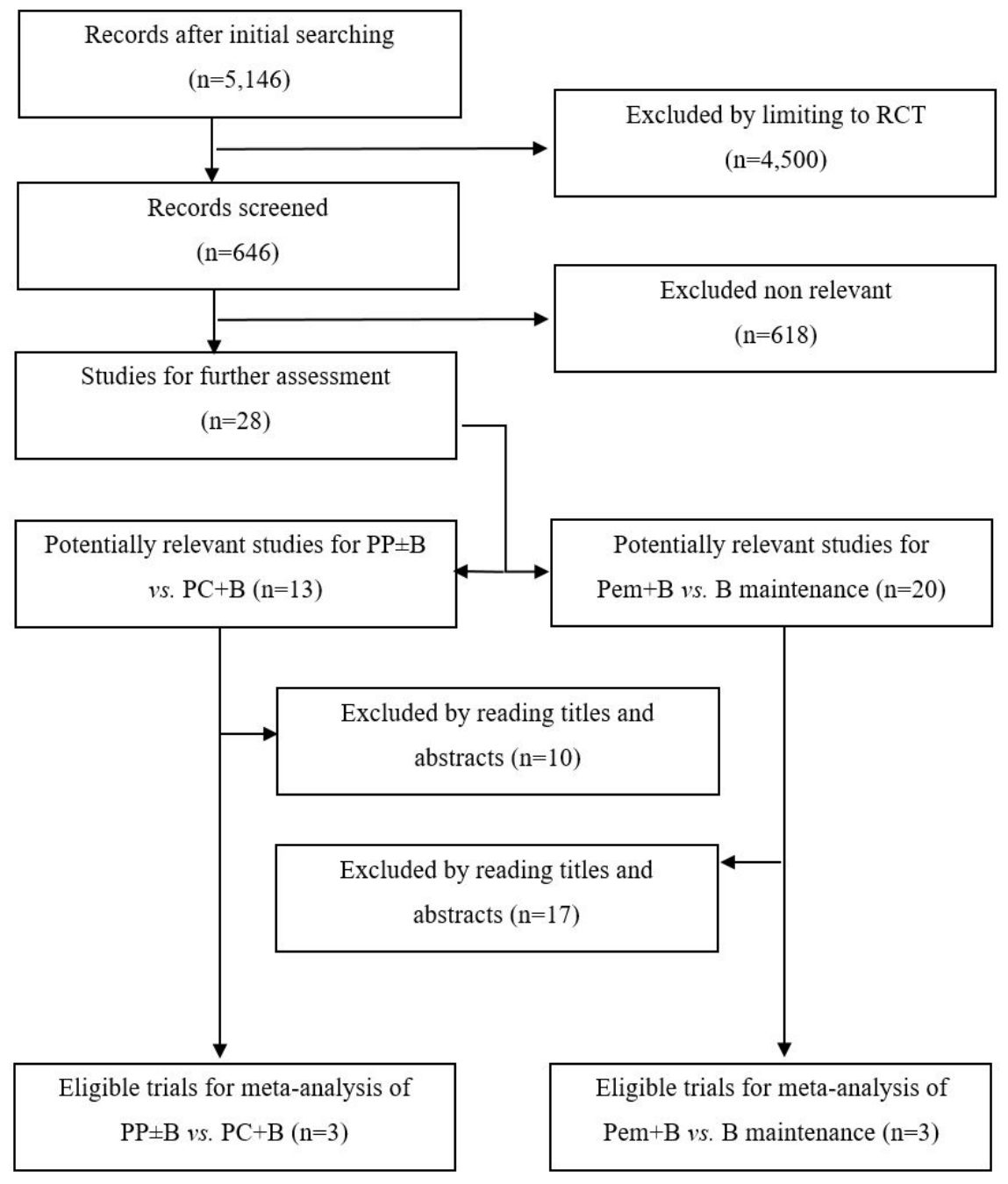

Figure 1

Overview of study search and selection.

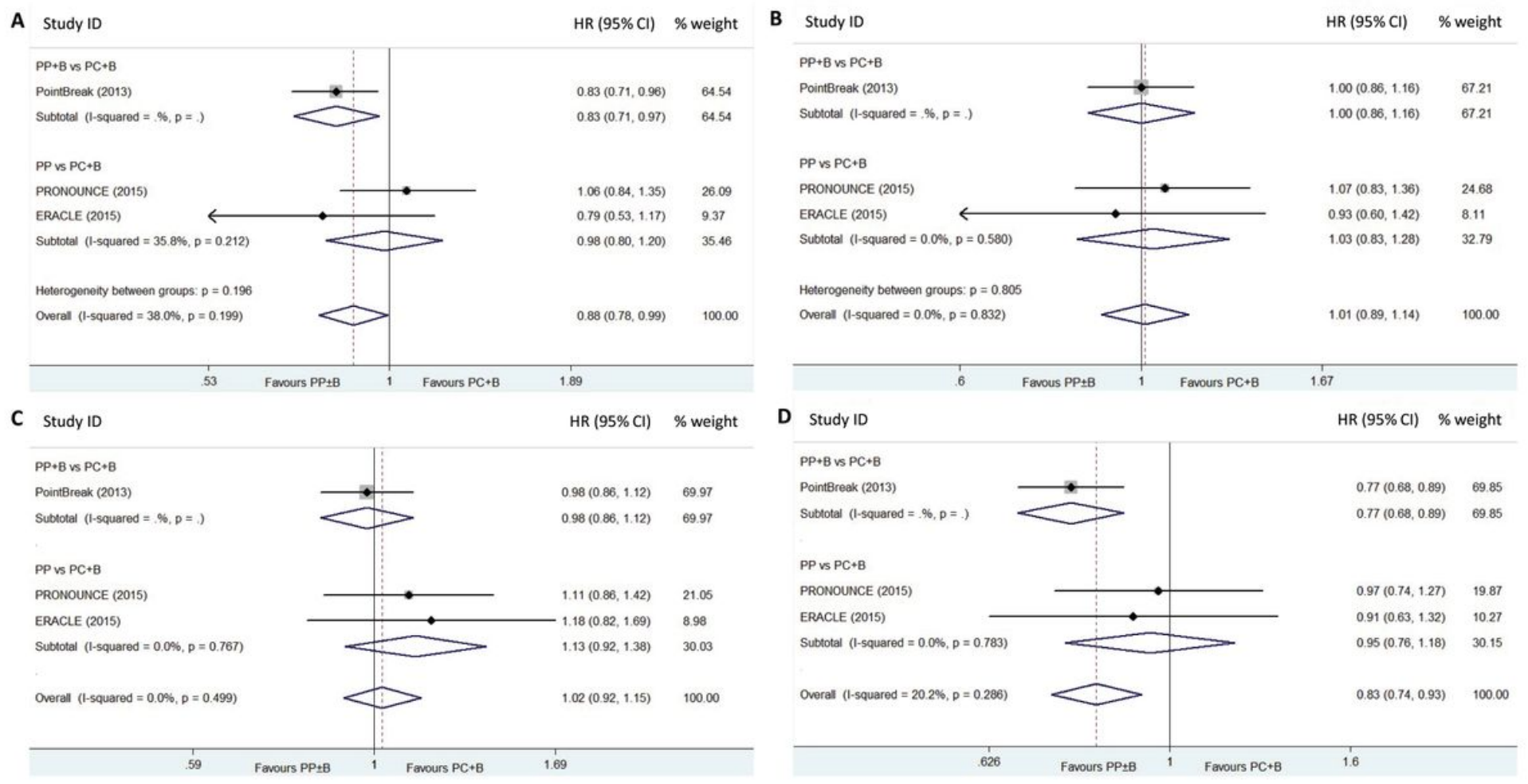


Figure 2

Efficacy comparison of first-line therapy between PP \pm B and PC+B. A. mPFS; B. mOS; C. ORR; D. PFSR1y. Abbreviations: PP $\pm B$, pemetrexed-platinum with or without bevacizumab; PC+B, paclitaxel-carboplatin with bevacizumab; mPFS, median progression-free survival; mOS, median overall survival; ORR, objective response rates; PFSR1y, 1-year PFS rate.

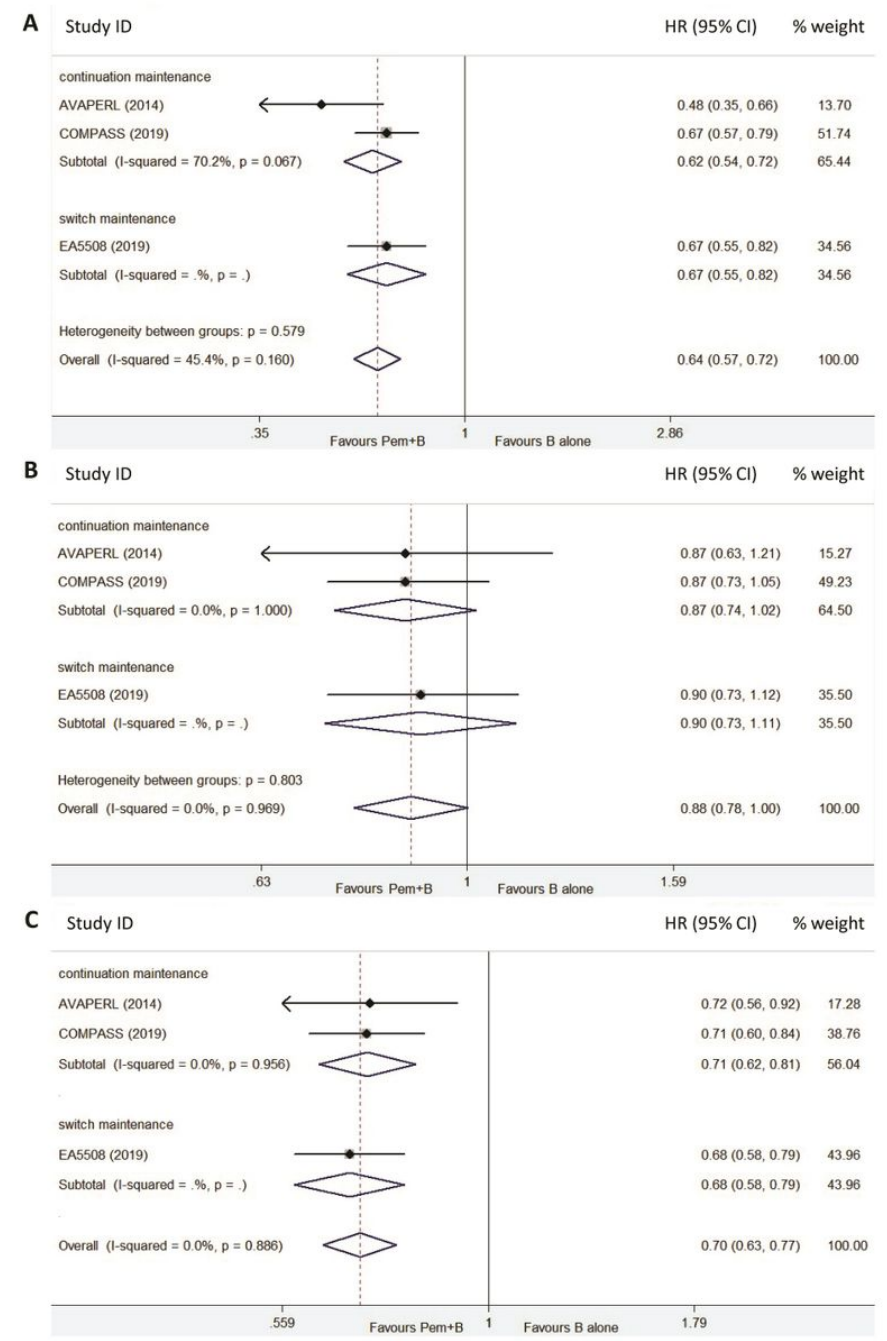

\section{Figure 3}

Efficacy comparison of maintenance therapy between Pem+B and B. A. mPFS; B. mOS; C. ORR. Abbreviations: Pem+B, pemetrexed and bevacizumab; B, bevacizumab; mPFS, median progression-free survival; $\mathrm{mOS}$, median overall survival; ORR, objective response rates.

\section{Supplementary Files}

This is a list of supplementary files associated with this preprint. Click to download.

- PRISMA2009ChecklistMSWord.doc 